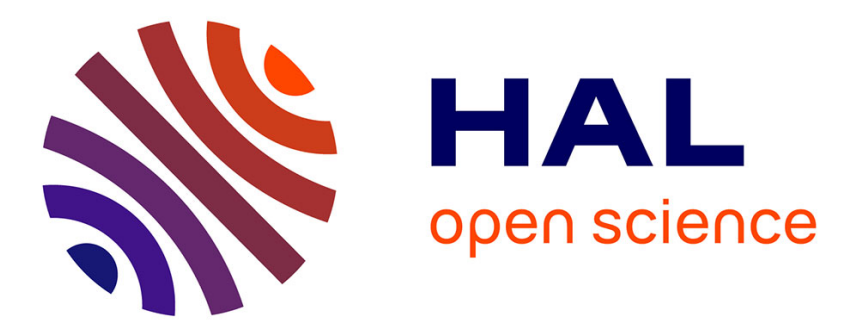

\title{
Indium antimonide infrared imaging C.I.D. linear and matrix arrays
}

\author{
J.P. Chatard, A. Lussereau, A. Salaville, M. Sirieix, Daniel Esteve, J.J. \\ Simonne, J. Farre, J. Rahobisoa
}

\section{- To cite this version:}

J.P. Chatard, A. Lussereau, A. Salaville, M. Sirieix, Daniel Esteve, et al.. Indium antimonide infrared imaging C.I.D. linear and matrix arrays. Revue de Physique Appliquée, 1978, 13 (12), pp.637-640. 10.1051/rphysap:019780013012063700 . jpa-00244517

\section{HAL Id: jpa-00244517 https://hal.science/jpa-00244517}

Submitted on 1 Jan 1978

HAL is a multi-disciplinary open access archive for the deposit and dissemination of scientific research documents, whether they are published or not. The documents may come from teaching and research institutions in France or abroad, or from public or private research centers.
L'archive ouverte pluridisciplinaire HAL, est destinée au dépôt et à la diffusion de documents scientifiques de niveau recherche, publiés ou non, émanant des établissements d'enseignement et de recherche français ou étrangers, des laboratoires publics ou privés. 


\title{
INDIUM ANTIMONIDE INFRARED IMAGING C.I.D. LINEAR AND MATRIX ARRAYS (*)
}

\author{
J. P. CHATARD, A. LUSSEREAU, A. SALAVILlE and M. SIRIEIX \\ Société Anonyme des Télécommunications, 41, rue Cantagrel, 75013 Paris Cedex, France \\ D. ESTEVE, J. J. SIMONNE, J. FARRE and J. RAHOBISOA \\ Laboratoire d'Automatique et d'Analyse des Systèmes du C.N.R.S., \\ 7, avenue du Colonel Roche, 31400 Toulouse, France
}

\begin{abstract}
Résumé. - L'intérêt est grand actuellement pour la réalisation de matrices plan focal sensibles à l'infrarouge thermique du type CCD, CID. Nous montrons dans cet article qu'il est possible de réaliser, malgré les difficultés inhérentes aux matériaux et aux techniques nouvelles, des matrices monolithiques sur InSb présentant des caractéristiques intéressantes et prometteuses. Des valeurs de détectivités de $3 \times 10^{11} \mathrm{~cm} \mathrm{H}^{1 / 2} \mathrm{~W}^{-1}$ pour une barrette linéaire de 32 éléments et de$$
5 \times 10^{10} \mathrm{~cm} \mathrm{H}^{1 / 2} \mathrm{~W}^{-1}
$$

pour une matrice de $8 \times 8$ éléments ont pu être mesurées qui sont très proches de celles obtenues sur les meilleurs détecteurs photovoltaïques. Les valeurs de rendement et de temps de transfert, obtenues par une modélisation et une analyse théorique, permettent d'établir la faisabilité de matrices comptant un millier d'éléments et lues par un seul préamplificateur.

Abstract. - It is of great importance to day to obtain thermal IR sensitive CCD or CID matrix arrays. This paper shows that it is possible, in spite of difficulties which appear with the new technics and material used, that monolithic InSb Arrays with good performances can be fabricated. Detectivities of about $3 \times 10^{11} \mathrm{~cm} \mathrm{H}^{1 / 2} \mathrm{~W}^{-1}$ for a 32 elements linear array and $5 \times 10^{10} \mathrm{~cm} \mathrm{H}^{1 / 2} \mathrm{~W}^{-1}$ for an $8 \times 8$ element matrix have been measured, which are very close to detectivities of best photovoltaic detectors. Efficiency and transfer time values are obtained via theoretical analysis and modelling which show the feasibility of a 1000 elements matrix array read by a single preamplifier.
\end{abstract}

1. Introduction. - A consequence of the evolution of infrared imaging systems has been an increase of the number of detecting elements located in the focal plane. The application of charge transfer devices in the infrared is now thoroughly investigated (see for instance [1]).

Two approaches are proposed :

a) hybrid devices in which the functions of detection and signal processing are performed on separate semi-conductor substrate [2],

b) monolithic devices including extrinsic silicon [3, 4] and narrow bandgap semi-conductors [5, 6].

Among the possible materials which can be used in the 3 to 5 microns spectral range, to realize a monolithic infrared imaging device with transfer read-out, Indium Antimonide has been selected owing to its interesting physical properties [7]. Working at $77 \mathrm{~K}$, many parameters like intrinsic density and mobility are in the same order of magnitude as those observed in silicon at room temperature.

However, the design and processing for silicon CCD or CID developed for the visible wavelengths, cannot be directly transfered to the IR and must therefore be reconsidered for InSb. The two salient features which can be underlined are :

- The maximum surface potential is limited by direct band to band tunnel charging currents owing

$\left(^{*}\right)$ Work sponsored by D.R.E.T. (Direction des Recherches Etudes et Techniques). to the narrow band gap of the semiconductor considered $[8,9]$ : As a consequence, a low doping density, and a high permittivity insulator should be used to increase the maximum charge storage capabilities. - In this wavelength range, high background photon flux, combined with the limited charge storage capabilities of the MIS device, need a trade off between spectral bandwidth, field of view and storage time while low thermal contrast requires a top level response homogeneity to decrease the subsequent fixed pattern noise [10].

2. Processing techniques. - Single crystals $\mathbf{N}$ type Indium Antimonide material fabricated in our Laboratories with low carrier concentration $\left(10^{14}\right.$ to $10^{15}$ carriers $/ \mathrm{cm}^{3}$ ) and low dislocation density (EPD : 100) were sliced into wafers. The surface was mechanically and chemically polished, and, after a standard cleaning process, the insulator thin film prepared and the semi-transparent gate sputtered.

A high quality native oxide cannot be achieved on InSb substrates [11] and involve the use of alternate insulator deposition techniques. Various dielectrics and deposition methods, completed with adequate annealing procedures, have been investigated :

- Joule heating $\mathrm{SiO}$, electron gun $\mathrm{Al}_{2} \mathrm{O}_{3}, \mathrm{CVD}$ SiON.

The best transition, close to $100 \mathrm{~Hz}$, between high and low frequency $C(V)$ curves has been achieved with $\mathrm{SiO}$, but interface state densities around 
$10^{12} \cdot \mathrm{cm}^{2} \cdot \mathrm{eV}^{-1}$ were measured, and a significant carrier trapping phenomenon due to high trap densities located in the insulator layers close to the interface, was observed on these structures [12]. Improvement of the surface characteristics and of the electrical breakdown of the insulator was obtained with CVD SiON.

3. Characterization. - Extended characterization of the elementary structure has been developed to check the value of key parameters as thermal filling rate, interface state profile, actual doping level [13]. In order to minimize the effects of shifts of the characteristics due to carriers exchange by tunnelling between the semi-conductor and traps in the first layers of the insulator, the pulsed $C-V$ characteristics method has been used. This technique allows both the obtention of the actual $1 \mathrm{MHz} C-V$ plot in the depletion region, from which the surface state density profile can be determined along the bandgap, and gives access to a direct measure of the thermal filling rate. Storage times $T_{\mathrm{S}}$ of $50 \mathrm{~ms}$, as defined in figure 1 have been commonly obtained. Doping density of the structures is deduced from the high frequency small signal capacitance which is measured using a PAR $410 C$ - $V$ plotter (Fig. 2).

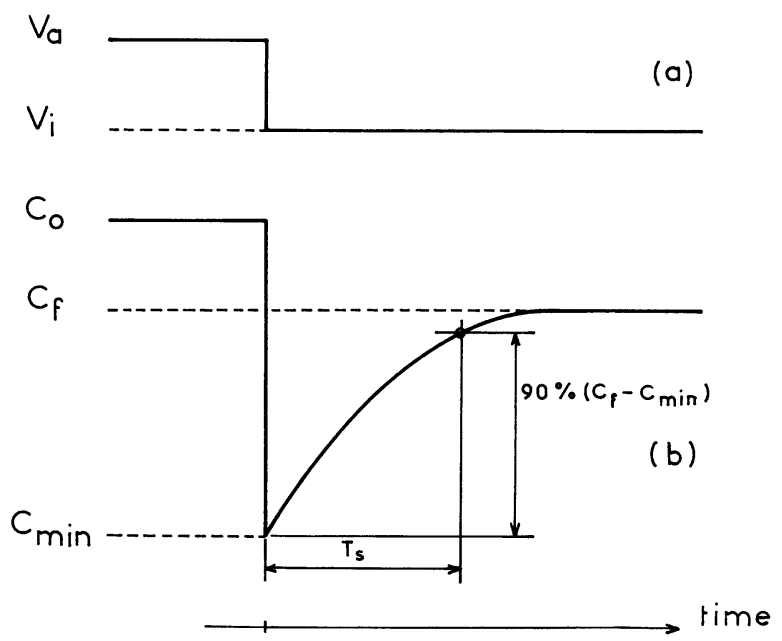

FIG. 1. - a) Gate voltage step. b) Transient capacitance showing Storage time $T_{\mathbf{s}} . V_{\mathrm{a}}$ Accumulation voltage; $V_{\mathrm{i}}$ Inversion voltage; $C_{0}$ Accumulation capacitance ; $C_{\mathrm{f}}$ Final capacitance (Steady State); $C_{\min }$ Minimum capacitance (transient).

4. 32 elements linear array. - Using a SiO deposited layer on Indium Antimonide material, a 32 elements linear array has been designed and built at SAT Laboratories (Fig. 2) whose dimensions of the sensitive area are $200 \mu \mathrm{m} \times 200 \mu \mathrm{m}$. A CID read out technique is performed by a charge sensitive amplifier, and the sequential adressing of the 32 elements is obtained through a Silicon shift register driving two silicon MOS switching transistors connected to each element. A schematic of the electronic control

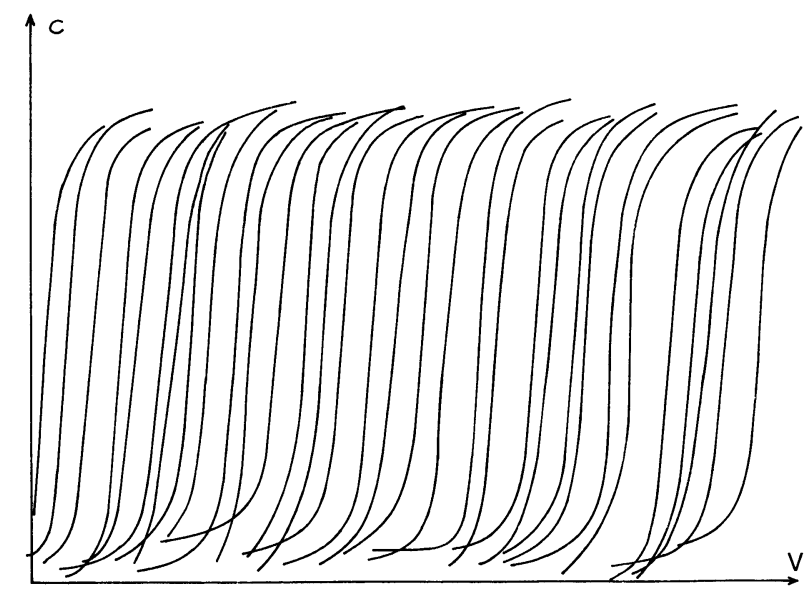

FIG. 2. - C-V Curves of elementary structures of a 32 MIS elements linear array showing a good reproducibility of the characteristics $(V$ scale $: 1 \mathrm{~V} / \mathrm{cm})$.

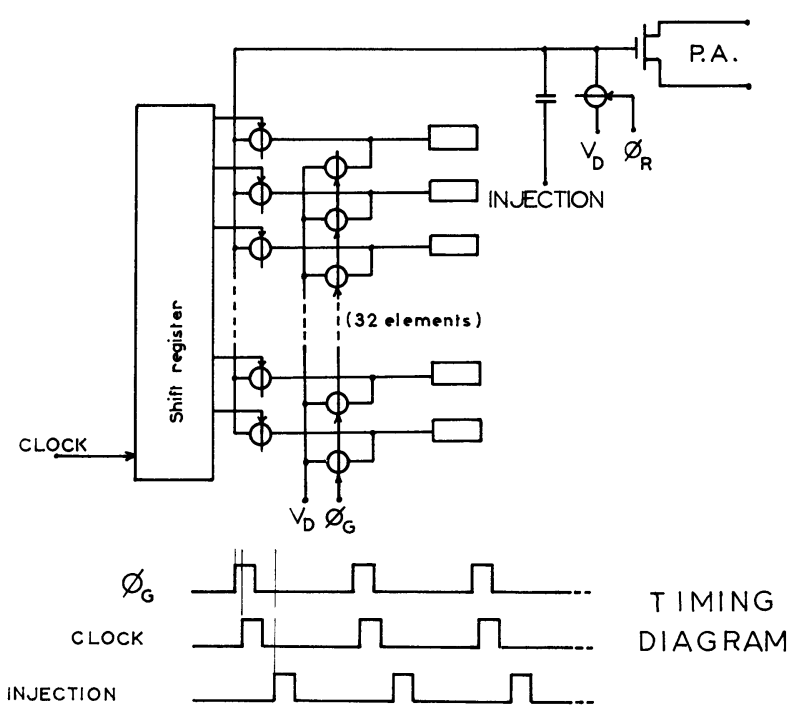

FIG. 3. - Schematic of a 32 MIS elements linear array read out circuit. $\varnothing_{\mathrm{R}}$ Reset control; $\varnothing_{\mathrm{G}}$ Gate control; $V_{\mathrm{D}}$ Depletion voltage ; P.A. Preamplifier.

circuit is presented on figure 3 . This array is packaged in a dewar, presenting a $15^{\circ}$ field of view and a cold infrared filter limiting the spectral bandwidth in the 3.7 to $4.8 \mu \mathrm{m}$ range. Under such conditions, relaxation times up to $1 \mathrm{~ms}$ have been measured in presence of room temperature background photon flux. Optoelectronic measurement shows a quantum efficiency around $50 \%$ and a detectivity up to

$$
3 \times 10^{11} \mathrm{~cm} \mathrm{~Hz}^{1 / 2} \mathrm{~W}^{-1}
$$

which is half of the BLIP detectivity (background limited operation).

These results, comparable to the sensitivity of the best photovoltaïc detector in the 3 to $5 \mu \mathrm{m}$ range, allow the realisation of an infrared imaging system. 
An image resulting from a $32 \times 64$ resolution points with a $0.1^{\circ}$ minimum resolvable temperature at a 25 frames/second rate, has been produced (Fig. 4).

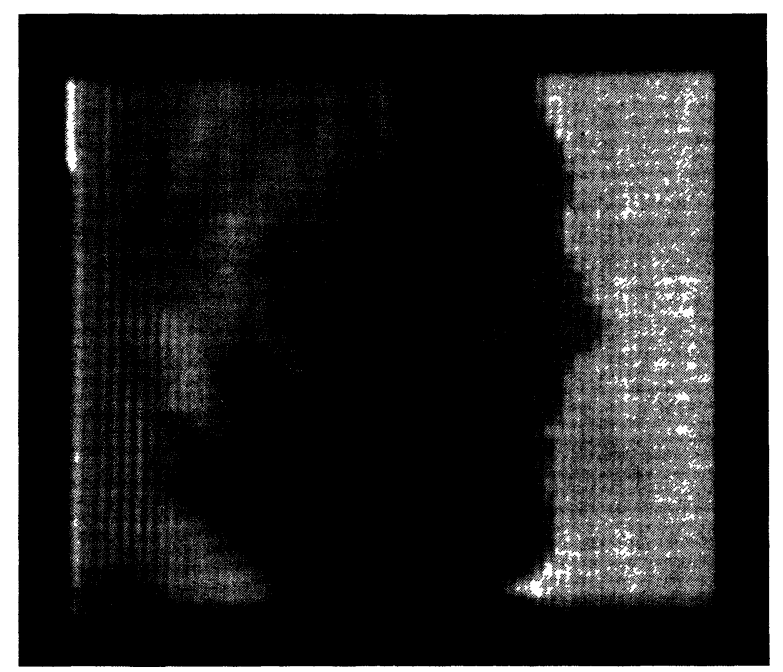

FIG. 4. - Photography showing a $32 \times 64$ resolution points imagery.

5. Charge transfer characteristics. - Transfer efficiency is the key parameter in two dimensional structures. After determining the MIS single structure characteristics, we have used a simplified model for the charge transfer between two neighbouring cells, based upon the thermal diffusion and the self induced drift mechanisms. This model is intended to define an optimum geometry of a CID elementary unit consistent with the design of a $8 \times 8$ elements imaging array.

In order to check this model and to measure the physical parameters governing the transfer efficiency, a test chip including several transfer cells with various geometries has been built. A multilevel layers process was necessary to realize overlapping gates in transfer cells, a photography of the corresponding chip is shown in figure 5 .

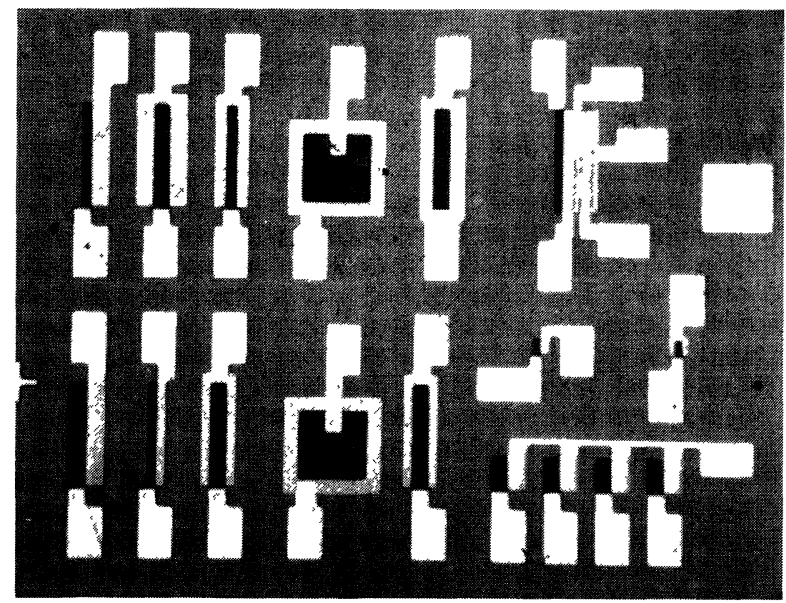

FiG. 5. - Test chip showing the variety of geometries of transfer cells.
The results are in good agreement with our model, transfer efficiency up to 0.97 has been obtained from the decreasing signal measured after 100 transfers between two neighbouring cells on structures presenting a $25 \mu \mathrm{m}$ gate length and a $1 \mu \mathrm{s}$ transfer time.

The two dimensional operation on a $4 \times 1$ array has been demonstrated.

6. Matrix array. - Based on these results, a $8 \times 8$ matrix array was designed and built. Overlapping electrodes and line crossing requires the use of 5 dielectric layers. To perform a high transfer efficiency and a good optical resolution, the dimensions of the sensitive area were limited to $35 \mu \mathrm{m}$ by $70 \mu \mathrm{m}$. Only the lower gate, connected to the row line is semitransparent; the upper gate connected to the column line is opaque (Fig. 6). Row and column lines are scanned sequentially to perform transfer between selected row and column cells, and to read out the column line by injection (Fig. 7). Integration time up to $1 \mathrm{~ms}$, cross talk lower than $2 \%$ and detectivity of $5 \times 10^{10} \mathrm{~cm} \mathrm{~Hz}^{1 / 2} \mathrm{~W}^{-1}$ have been measured on this device.

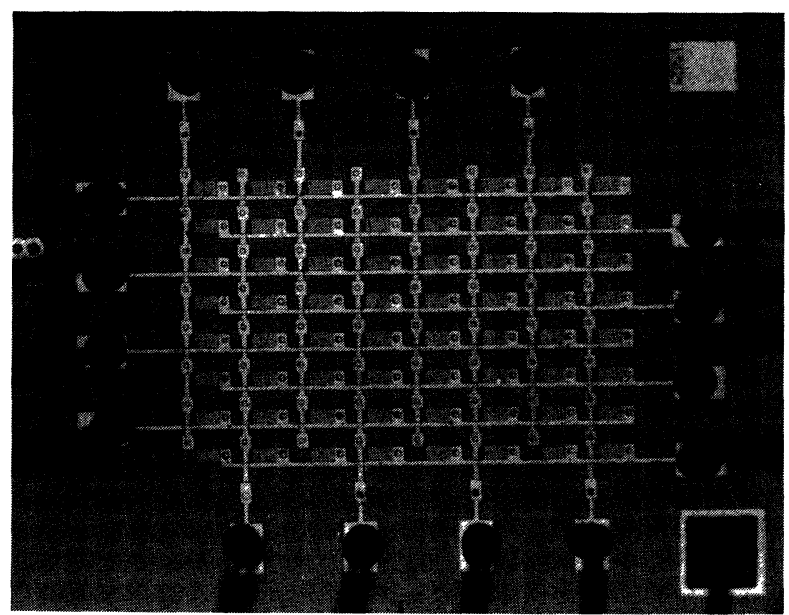

FIG. 6. $-8 \times 8$ matrix array showing the semi-transparent row lines and the opaque colum lines.

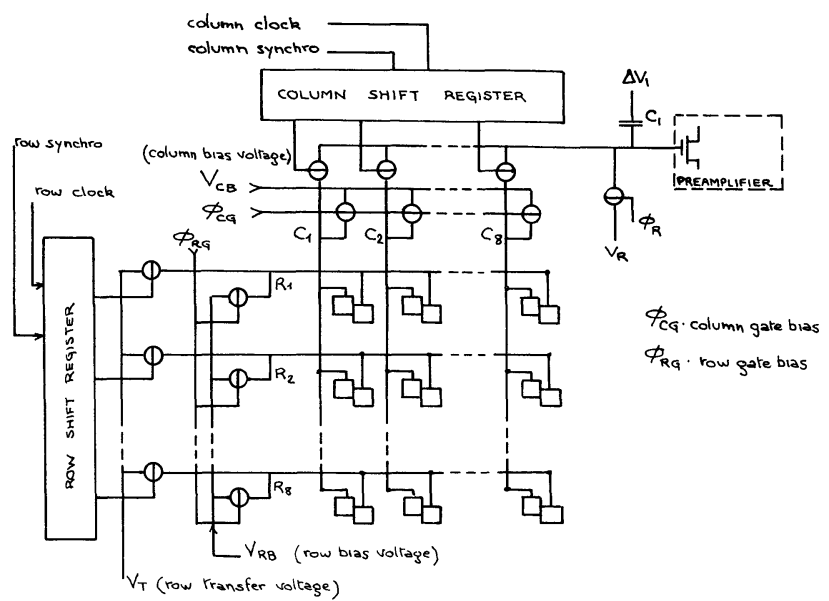

FIG. 7. - Schematic diagram of two dimensional $(8 \times 8) \mathrm{InSb}$ CID array configuration. 
7. Conclusion. - Indium Antimonide MIS structures have been fabricated and tested. Promising results on simple structures, multielements linear and matrix arrays, show that these devices are prime candidates for IR systems operating in the 3 to $5 \mu \mathrm{m}$ spectral range.

Sequential read out and transfer are the key parameters to integrate a high density of sensor cells in a focal plane with minimum electronic circuits. Theoretical analysis and modelisation based on physical parameters have shown that starring time in the order of $1 \mathrm{~ms}$ and read-out time lower than $1 \mu \mathrm{s}$ can be achieved, demonstrating read-out capability of 1000 elements matrix array with only one preamplifier.

\section{References}

[1] STECKL, A. J. et al., "Application of Charge-coupled Devices to Infrared Detection and Imaging ». PIEEE 63 (1975) 67.

[2] Steckl, A. J. and Koehler, T., "Theoretical Analysis of Directly Coupled 8-12 $\mu \mathrm{m}$ Hybrid IRCCD Serial Scanning ». In Proc. CCD Applications Conf. (1973) 247-258.

[3] Nummedal, K. et al., "Extrinsic Silicon Monolithic Focal Plane Array Technology and Applications ". In Proc. CCD Applications Conf. (1975) 19-30.

[4] Sclar, N. et al., "Silicon Monolithic Infrared Detection Array ». Appl. Opt. 16 (1977) 1525.

[5] Phillips, J. D., Scorso, J. B., Thom, R. D. and Eck, R. E., «InSb CCDS and other MIS Devices for Infrared Applications ». In Proc. CCD Applications conf. (1975) 31-41.

[6] Kim, J. C., Davern, W. E. and Colangelo, D., « InSb CiD Infrared Imaging Devices". In Proc. of International Electron Devices Meeting (1976) 550-554.

[7] KIM, J. C., «InSb Technology and CID Devices ». In Proc. CCD Applications Conf. (1975) 1-17.

[8] Farre, J., Buxo, J., Esteve, D., Importance relative des composantes de courant de charge dans les capacités
M.I.S. destinées à détecter le rayonnement Infrarouge. C. R. Hebd. Séan. Acad. Sci. 283B (1976) 103-106.

[9] ANDERson, W. W., Tunnel current limitations of narrow bandgap Infrared charge coupled devices. Infrared Phys. 17 (1977) 147-164.

[10] Sirieix, M., Garcia, M., Farre, J., Simonne, J. J., HgCdTe M.I.S. Structure : modelling and application to charge coupled device infrared Imagery 18 (1978) 233.

[11] Wilmsen, C. W., Oxide Layers on III. V. Compound semiconductors. Thin Solid Films 39 (1976) 105-117.

[12] Buxo, J., Esteve, D., Farré, J., Sarrabayrouse, G. and SimONNE, J., " A model for the large-amplitude hysteresis in MIS structures on InSb ». Appl. Phys. Lett. 33 (1978) 969-971.

[13] Esteve, D., Simonne, J., Farré, J., Sirieix, M.. " Theoretical limitations of narrow bandgap semiconductor MIS devices used for IR imaging detectors ». Presented to the Charge coupled device Conference, Oct. 1978, San Diego, Calif. 